DOI: $10.20472 /$ IAC.2017.032.020

\title{
GIULI KESHELASHVILI
}

Ivane Javakhishvili Tbilisi State University, Georgia

\section{CHARACTERISTICS OF MANAGEMENT OF AGRICULTURAL COOPERATIVES IN GEORGIA}

\begin{abstract}
:
Work provides overview of the situation and trends in agricultural sector of Georgia. It mentions that Georgia is a country with small land area, where, as a result of improper land reform the lads were excessively fractured, with $75 \%$ of population holding up to 1 ha arable land. Working of such small parcels is unreasonable and economically ineffective. Taking this issue into consideration, for the purpose of stimulation of creation of the small farmers' associations, the legislative incentive was prepared on creation of the agricultural cooperatives. As a result of joint work of the Ministry of Agriculture and Agrarian Committee of the Parliament, on 12 July 2013, the Parliament of Georgia adopted the Law on Agricultural Cooperatives. On the basis of this law the LEPL Agricultural Cooperatives Development Agency was established to provide state support to the agricultural cooperatives. The main goal of the Agency is promotion of rehabilitation of the rural areas and agriculture through development of agricultural cooperatives.

Of key legislative acts dealing with the activities of agricultural cooperatives, Georgian Law on Agricultural Cooperatives prevails over Georgian Law on Entrepreneurs. Therefore, the legal relations of the agricultural cooperatives are regulated by Georgian Law on Agricultural Cooperatives. According to the mentioned Law, the cooperatives provide regulation of the internal production relations by means of the economic participation, obligatory participation contributions, associated members of the cooperatives and other elements. The labor relations are decisive factors.

Work provides analysis of the key operation principles of the agricultural cooperative; characteristics of cooperatives management provided for by the Law on Entrepreneurs and Law on Agricultural Cooperatives; rights and obligations of the cooperative shareholders; conflicts arisen in the course of performing of contracts made between the agricultural cooperative and its shareholder; agricultural cooperative monitoring functions. On the basis of analysis of legal regulations of leading European countries dealing with the cooperatives the recommendations are provided for improvement of cooperatives management in Georgia, for development of the entire cycle of production and sale of agricultural goods allowing generation of the increased incomes from sale of the end products by primary goods producers without any middlemen.

The conclusion is made that formation of the cooperation systems of European type would be much more beneficial for the farmers, as well as for the country and its final results will be seen in its socioeconomic effects.
\end{abstract}

\section{Keywords:}

Keywords: agricultural cooperative, economic participation, shareholder, management organizational structure.

JEL Classification: M10 


\section{Introduction}

Georgia is a country with scarce land resources. Development of the agriculture sector still remains one of the main challenges of Georgian economy. Agrarian sector plays leading role in Georgian economy though since 1990, from year to year, shares of agriculture, hunting, forestry and fishing in GDP is characterized with the reduction trend. The sector, where, according to the official statistical data, $43 \%$ of Georgian population is employed, provides only $9.2 \%$ of GDP. Currently, in Georgia, $80 \%$ of the agricultural products are imported. Crisis in agrarian production further strengthens motivation of support to agriculture sector and its regulation of the state. Currently the government makes certain steps in this respect. The issue of creation of the cooperatives is of particular significance. Most rural population owns very small land parcels and incomes from farming is not sufficient for their families. Therefore, unification of the agricultural capacities, i.e. cooperation is a significance way for improvement of the population's social condition.

Development of the cooperation process commenced in the $19^{\text {th }}$ century, in the Europe, where cooperative organizations appeared in the different countries. In Germany the first credit cooperatives were established, in England there were the consumers' cooperatives and in France - production cooperatives. Immediately upon establishment of United Nations Organization, the economic board for studying of the cooperative issues was formed and in its first resolutions the board added special role to the cooperation. Currently the cooperatives operate in all countries all over the world with over billion people involved. The agricultural $(30 \%)$, trade $(23 \%)$, insurance $(22 \%)$ and credit $(19 \%)$ cooperatives are the most widespread ones.

Business oriented cooperatives play critical role in the agriculture structures of the European states. In the European states most small farmers are engaged in the primary production. Most of them are unified in the cooperatives. Number of the members of agricultural cooperatives, in the $\mathrm{EU}$, is about 9 millions, i.e. two of every three farmers are the cooperative members. $60 \%$ of agriculture goods production, processing and marketing fall on the cooperatives. Total capital turnover of the EU agricultural cooperatives is as much as Euro 260 billion.

Current political and economic problems in our country are directly linked with the socioeconomic processes of late $19^{\text {th }}$ and early $20^{\text {th }}$ centuries. Formation of the agriculture cooperatives commenced in the second half of $19^{\text {th }}$ century. In 1909, a book by Konstantine Kandelaki: "Cooperation. Theory, History and Practice" was published in Tbilisi. From 1911, in Kutaisi, the magazine "Cooperation" have been issued, periodically publishing all news related to the mentioned issue. The readers had the opportunity to get familiarized with the experience and achievements of the European countries in this area. There have been arranged the lectures about this issue and the scales of cooperative work became wider with time. The magazines and newspapers of that period used to publish articles describing 
how glad people were because of the cooperatives' establishment. People believed that the cooperatives would be significant instrument for economic growth and overcoming of the poverty. In that period numerous cooperatives were established, unifying hundreds of subjects, e.g. the cooperative of shepherds "Mtskemsi" (Shepherd), trade partnership "Kolkhida", "Avlevi" farming partnership, trade partnership "Shuamavali" (Middleman) etc. The partnerships had the commercial relations with the leading European countries. Scale of their activities, markets and profits from products' sale increased permanently. In this respect, in Georgia, the most successful was Kakheti Region, where the viticulture cooperatives were mostly established. In 1921, about 900 cooperatives operated in Georgia, with over one million members. Georgia was involved in the process of dynamic and democratic development. Soviet occupation eliminated private property and management experience of the agricultural cooperatives. After occupation (1921), as a result of collectivization process, the cooperatives were finally destroyed and some of their leaders killed. With time, everything was forgotten. ,After the collapse of Soviet Union, the collective farm lands were transferred to the peasants - initially for lease and later for private property. However, this process was not boosted by the privatization of the material assets of the collective farms - the inexperienced lawmakers simply forgot about it153. Former bosses of the collective farms took immediate advantage of the circumstance and sold whole technical equipment - vehicles, tractors, combines - mostly to Turkey as scrapiron"[Tvalchrelidze A. Silagadze A. Keshelashvili G. Gegia D. (2011)].

Currently, the issue of creation and development of the cooperatives is one of the main challenges of Georgian Agrarian Sector. Development of small farming can significantly contribute to socio-economic development and improvement of living conditions for a large number of populationin Georgia. Nowadays, there are mostly smallscale farms in the country and they mainly produce only for self-consumption. In fact, population of the country consumes more imported goods than it produces. [Kharaishvili, E. (2016)].

\section{Foreign Experience of Agricultural Cooperatives' Management}

Examples of the successful cooperatives in the world's leading countries provide interesting information for practical generalization of their experience in Georgia. Study and sharing of the international experience is decisive for improvement of the agriculture cooperatives' management effectiveness. For this research we selected the countries that provide an example of successful reforms for us. In these countries the legal regulations for the cooperatives are based on the constitution, civil, administrative, cooperatives', banking and tax legislations. For example, in Germany, the cooperative activities are based on German Federal Law Commercial and Economic Partnerships adopted in 1889; in Great Britain on the Law on Industrial Associations and Benefit Societies. In Portugal, the basis of legislation dealing with the cooperatives is the Cooperative Code. Here the cooperatives are the legal entities with special legal status that imply certain tax exemptions for the 
cooperatives. Support activities from the state are provided by the cooperatives development program. In Japan there are different legal regulations for the agricultural cooperatives and consumers' cooperatives. Legal regulations for the agricultural cooperatives are provided in the Law on Agricultural Cooperation (1947). Here, the agricultural cooperatives imply production, marketing, procurement of the production factors, consultations, credit and insurance cooperatives. $90 \%$ of Japanese farmers are members of the agricultural cooperatives. Legal regulations of the consumer cooperatives are provided in the Law of Japan on Consumer Cooperation (1948), In Italy, the legal status of the cooperatives are determined by the different laws, e.g. Article 45 of the Constitution, stating that the "Republic recognizes social function of the cooperation". Cooperation purposes are formulated in the Civil Code of Italy specifying that the goal of cooperation is providing for its members services and work conditions better than those at free market. In Ukraine all legal entities are classified as the entrepreneurial and non-entrepreneurial societies. The production cooperatives are recognized as the entrepreneurial societies and the consumer cooperatives - as the non-entrepreneurial cooperatives. Legal status of the non-entrepreneurial society is determined by the Civil Code of Ukraine. In Denmark and Belgium there are no legal acts regulating the cooperatives' activities and the key legal acts that would regulate their operation. Here the cooperatives' activities are regulated by the internal normative acts developed by the cooperatives. In these countries the cooperative movement is at quite high level. For example, in Denmark, starch producing cooperative unifies over 3000 farmers, with 5 enterprises, producing 170000 tons of potato starch per year. $85 \%$ of their products are exported and sold in over 40 countries.

According to the world experience, the most important benefits for the cooperative members resulting from cooperation include availability of the equipment, plants and machinery, market and information; improvement of availability of the specialization and distribution of work. There are two types of agricultural cooperatives: production cooperatives and service cooperatives. In the production cooperatives the members jointly produce the goods; they have production factors in joint ownership (land, buildings and structures, equipment; mechanization etc.) and jointly use them. Economic activities of the production cooperatives are based on the consolidated production factors. In the opinion of some scientists, this provides certain advantages compared with small individual farms. Researches in the countries with market economy show that we have no economy of scale at the level of initial agricultural production. Moreover, in many cases it turns out that the production cooperatives are less effective than individual farm economies. This is also confirmed by the fact that, according to International Cooperatives Alliance (ICA) data, share of the production cooperatives in global cooperation system is no more than $5 \%{ }^{1}$. Service cooperatives are most widespread form of cooperatives in the world. In the associations of this type the cooperative members do not consolidate the property and production factors. The cooperative allows its members procurement of the production

\footnotetext{
${ }^{1}$ International Co-operative Alliance, https://ica.coop/
} 
assets at relatively low prices (if before unification, they, individually, provided the retail demand, after unification they create the wholesale demand); consolidate the products, process them and sell jointly; provide joint marketing; receive industry and other consultations. Share of the service cooperatives in the agricultural transactions in the developed countries is highest, comprising, for example, 30\% in USA, 50\% in EU and almost $85 \%$ in Japan ${ }^{2}$.

\section{Analysis of Agricultural Cooperatives' Management in Georgia}

Poorly conceived land reform in 90 s of the $20^{\text {th }}$ century resulted in excessive fracturing of the lands in Georgia. Over $90 \%$ of the population owns the agricultural parcels up to 2 hectares only and work on such land parcels is ineffective. For the purpose of dealing with this problem and helping small farmer the extensive work for creation of the agricultural cooperatives have commenced. With respect of the state policies dealing with the cooperatives significant steps were made in 2013, when the Agency for Development of Agriculture Cooperatives was established. In the same period Georgian Law on Agricultural Cooperatives was approved. Significant institutional basis was created to support development of the cooperatives.

Georgian Law on Agricultural Cooperatives set the organizational norms for establishment and operation of the agricultural cooperatives. This Law has certain advantages compared with Georgian Law on Entrepreneurs regulating relations with the enterprises of all types of organizational-legal forms. Georgian Law on Agricultural Cooperatives regulates such issues as: key principles of the agricultural cooperatives' founding, democratic management, goals of the agricultural cooperatives, spheres of activities of agricultural cooperatives, functions of the Agriculture Agency, award and termination of the agricultural cooperative status, monitoring of the cooperatives' operation, cooperative membership, the members rights and obligations, rules of making contributions by the members, types of shares, distribution of profits of the agricultural cooperatives etc. In addition to the mentioned law, the organizational structure of agricultural cooperative and internal production relations are regulated by the cooperative's charter and agreement made between the cooperative and its member.

The cooperative is based on the principles of voluntary membership, dedication to business, leadership, sound and effective management. Modern cooperative allows the small farmers building his/her business based on the democratic principles. In our country, membership of agricultural cooperative is voluntary, its management is provided according to the democratic principles: all members are equal, irrespective of the size of contribution, whether it is 100 ha or 1 ha agricultural land.

2 International Co-operative Alliance, https://ica.coop/ 
In all cases each member has one vote. The key principles of the cooperative's operation are as follows: voluntary membership; democratic management; economic participation of members; social responsibility, fairness and mutual assistance.

Cooperative management is provided by the management and control bodies elected at the general meeting. Management bodies include the supervisory board, representatives' meeting and management board while the control body is the revision commission. Cooperative members control functioning of the management bodies at all levels of production activities. Democratic form of management allow the cooperative protecting and maintaining its identity, qualities and values thus making it substantially different from the enterprises of other organizational-legal forms. Economic participation is determined by the agricultural goods produced and delivered by the member within the scopes of agricultural activities or share of the delivered services. "Economic participation" shows the member's function of being directly involved in the activities of cooperative. Unlike the Law on Entrepreneurs, where the cooperative members are entitled to the dividends proportional to their contributions, according to the Law on Agricultural Cooperatives, the member is entitled to the dividend proportional to his/her economic participation.

Monitoring of the agricultural cooperatives is provided by the Legal Entity of Public Law, Agricultural Cooperatives Development Agency (ACDA) subordinated to the Ministry of Agriculture of Georgia. The Agency examines compliance of the cooperative's activities with the requirements of Georgian Law on Agricultural Cooperatives by means of scheduled and unscheduled monitoring activities. In case of the scheduled monitoring, the agricultural cooperative shall be given one month prior notice. If there is a suspect that the agricultural cooperative violates the requirements of Georgian legislation, the Chairman of the Agency instructs the authorized persons to conduct unscheduled monitoring. If the monitoring shows that the legal requirements are not complied with, the cooperative status is terminated.

Main goal of the Agricultural Cooperatives Development Agency is to offer the farmers such mechanisms that would promote successful operation and long-term development of the cooperatives and this implies creation of the new jobs, introduction of advanced technologies, land consolidation, growth of agriculture and export potential of the country.

As of 1 January 2017, in Georgia, there are registered 1586 agricultural cooperatives distributed by the regions as follows (See Fig. 1): Kakheti - 156; Kvemo Kartli - 224; Mtskheta-Mtianeti - 86; Shida Kartli - 119; Samegrelo - Zemo Svaneti - 127; Guria - 53; Adjara - 155; Samtskhe-Javakheti - 358; Imereti - 124; Racha-Lechkhumi - 132; Tbilisi $-52^{3}$. In Racha-Lechkhumi and Kvemo Svaneti regions the cooperatives are distributed

\footnotetext{
${ }^{3}$ Agricultural Cooperatives Development Agency, http://acda.gov.ge/index.php/geo/static/118
} 
most uniformly, while their distribution is most uneven in Samtskhe-Javakheti region. Here the cooperatives mostly produce the potatoes.

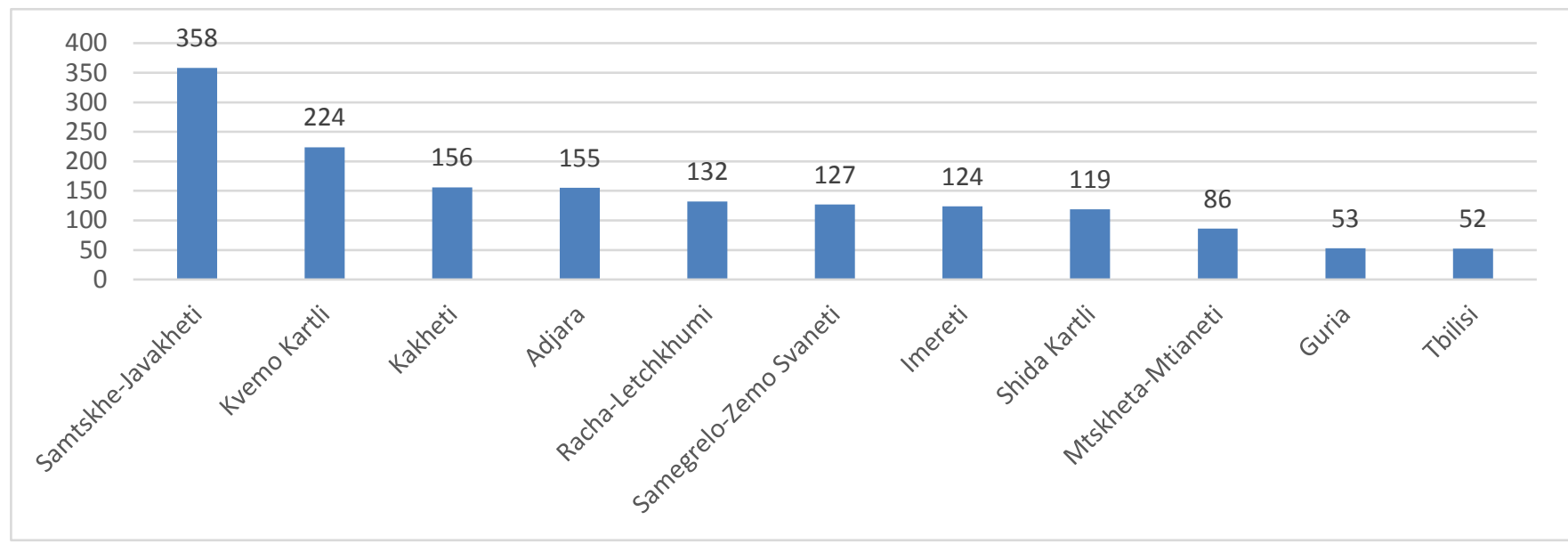

Fig. 1 Number of agricultural cooperatives by the regions of Georgia as of 2017

The survey, within the scopes of our study, showed that for the cooperatives operating in Georgia inn year 2017, the most important benefits included high incomes, production growth, employment, improvement of the products' quality, improvement of availability of the raw materials, supplies, infrastructure and market.

In studying of the agricultural cooperatives management process, we have applied qualitative research methods, in particular - the interviews and focus group meetings conducted for problems identification. In the process of research the information was collected about the following issues: management organizational structure, communication and decision-making process, organization strategies, professionalism and qualification of the employees, development of the staff potential.

Among the agricultural cooperatives, the bee-keeping, dairy production, hazelnut production and viticulture cooperatives the most widespread ones. The stratum of winemakers with wineries equipped with low capacity though state-of-art materialtechnological basis, with adequate raw materials supply is formed in Georgia. Wines produced by them are distinguished with fine quality and they are successfully sold at domestic and foreign markets [Keshelashvili G. 2016].

Cooperative Darcheli, established in 2015, in village Darcheli, is a hazelnut producing cooperative with 516 members, mostly engaged in primary hazelnut production and processing. The production cycle includes hazelnuts production, storage, removal of the shells and drying. If this cooperative was formed as the second level integrated cooperative enterprise, it would include hazelnut production, warehousing, drying, shelling, roasting, grinding, packaging and sale. 
Based on information collected through interviewing of the cooperatives in various sectors there were identified the following positive outcomes resulting from development of agricultural cooperatives in Georgia: after association the farmers were able to manufacture the end products and deliver them to the consumers; the products range increased, the sphere of the cooperatives activities expanded and products' quantity and quality improved; the farmers gained better availability of market, the cooperatives produced marketable goods and they were able to distribute them through network of stores.

The research identified the following factors affecting cooperatives' management: farmers' education level, scope of the assets owned by the cooperative members, stability of the legislative environment, specific nature of the cooperative's activities and business management skills.

Lack of experience is a typical problem. The cooperatives are mostly managed by the general meeting, it elects the management board and the latter board elects the chairman. Frequently the chairmen have no leadership and management skills. The farmers have no long-term vision, most of them are oriented to one-year yields and they are not able to develop their economies in a consistent manner. General lack of the highly qualified professionals - the accountants, finance managers and specialists in agriculture is the problem for effective operation.

The main problem for sustainable development of the cooperatives and improvement of their effectiveness is the size of cooperatives. Most of the existing cooperatives are of "family" type. Most of the cooperatives were established for the purpose of gaining funding from the state and trust to the idea of cooperation and attraction of the new members is still very low. In Georgia, numbers of cooperative members are quite low. Most of the cooperatives have 3 or 5 members to meet the minimal legal requirements and due to this, the cooperatives earn low incomes and they are not the promising ones, in economic respect. The cooperatives and their members are mostly focused on the short-term benefits as they have no sufficient assets for business development.

The main source of information for the cooperatives is the local information and consultation centers. They provide information about ACDA programs, as well as various state and international assistance (see Fig. 2). Cooperative members receive information mostly through group meetings, booklets, press and TV. Only few of cooperatives can gain information from internet. 


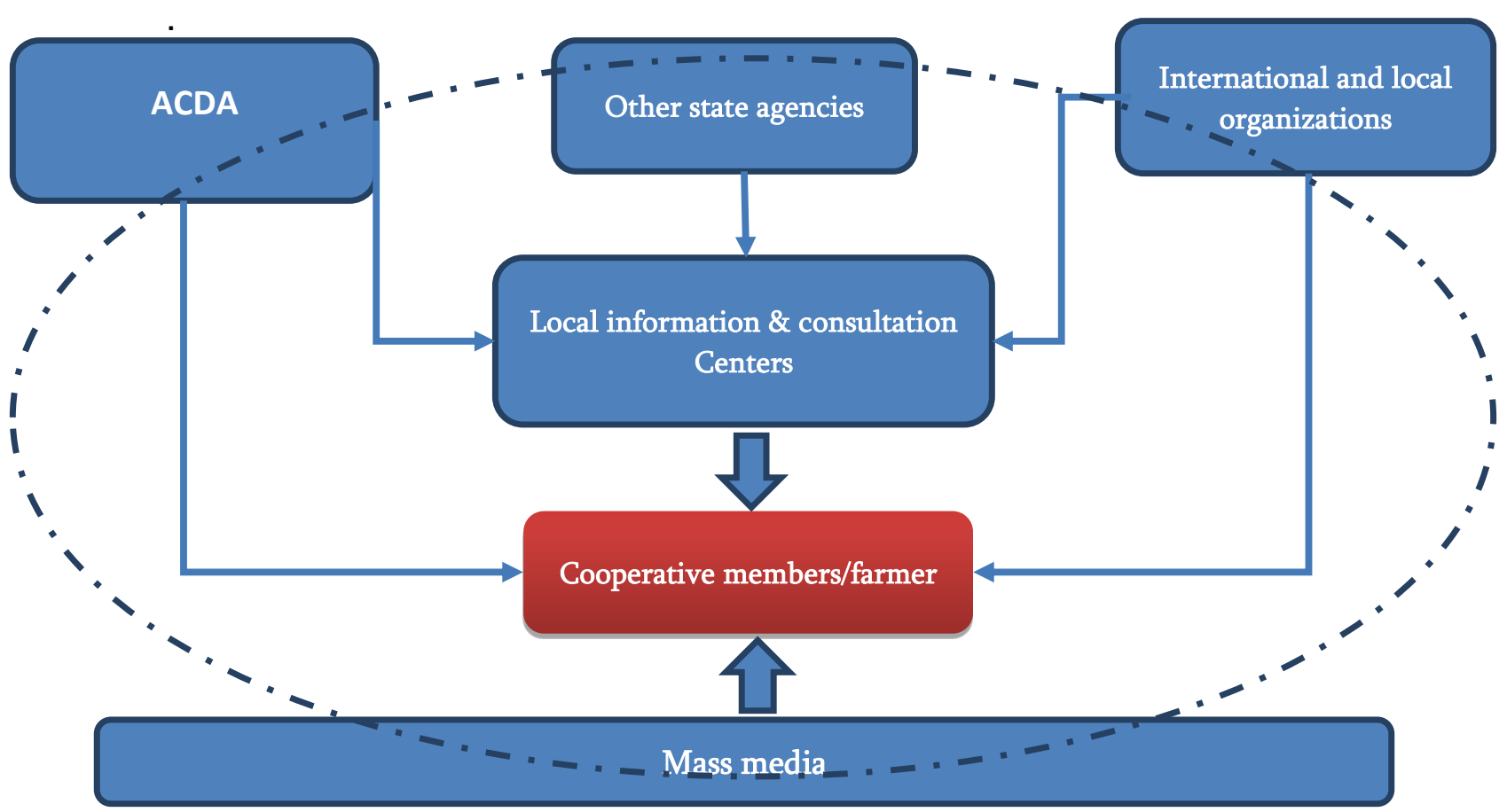

Fig. 2 Information channels used by the agricultural cooperatives in Georgia

Permanent re-training of the personnel employed by local consultation \& information centers is of great significance, as well as providing relevant knowledge and information to them, conducting of information campaigns in mass media, whether this is radio or television. These communication instruments are of particular significance for demonstration of the strengths of cooperation. Wide spreading of information about successful cooperatives is necessary. This would significantly improve the farmers' motivation. In addition, such approach can be used to interest the young people as well. It is recommended to gain support of the state and investors in introducing the ERP systems to small and average companies [Seturidze, R. (2016)]

Decision-making process in the cooperatives is quite difficult. Cooperative is a bureaucratic organization. It is managed by general meeting. It elects the managing directorate from the cooperative members. The cooperative is founded by joint decision of the members. Each of the cooperative members has one vote, irrespective of their share. Therefore, to make decision, the members require consensus.

In many cases the agricultural cooperatives have no formulated mission, goal and objectives. They are mostly founded for short-term benefits (to receive machinery, grants and other benefits). Influence of the traditional agricultural practices is significant as well. The farmers basically rely on the experience of previous generations, with little attention to 
the innovations. Application of the legal regulations related to the products quality in practice is a serious problem for the cooperatives.

Population produces agricultural goods with the traditional knowledge. They have no information about modern production technologies to improve productivity and goods quality. Industry trainings are especially needed. Emphasis should be made on delivery of knowledge of modern technologies and their practical application. Actually, most of the farmers have no any knowledge about agricultural business management, planning, profitability evaluation, financial calculations and business-related issues.

Development of science is increasingly focused on small, medium and large enterprises, on the economic and social motives and future trends of the development of the country [Keshelashvili G. Jibuti M. (2015)].

\section{Conclusions and Recommendations}

Based on the analysis of the results of our research we regard that for improvement of agricultural cooperatives management, the following is of significance:

- Long-term strategic planning of the state support programs based on the specific indicators taking into consideration the strategic goals of the agricultural cooperatives development;

- Support to introduction of technical regulations for the purpose of improvement of the quality of produced goods;

- Support to improvement of the cooperative members' qualification;

- Creation of the entire cycle of agricultural goods production, processing and sale in the cooperatives, where the product manufacturers will receive increased revenues from sale of the products without any intermediate cycles;

- European-type two- and three-level cooperation system based on the vertical integration principle should be created to unify production, processing, distribution and marketing cooperatives for the purpose of growth of incomes;

- Stimulate creation of large cooperatives (e.g. with 50 members) instead of the ones with 3-5 members, first-level cooperatives should be formed with expanded functions;

- Together with products' branding and popularization, support to market access and sales should be provided. 


\section{References}

Chokheli, E. (2015) Role of the Organizational Design in the Company's Success. European Scientific Journal, 91.

Chokheli, E. (2016) The Impact of the Competitive Strategy on the Success of Wine Companies (The case of Georgia), Proceedings of 24th international academic conference, Barcelona.

http://www.iises.net/proceedings/24th-international-academic-conference-barcelona/table-ofcontent/detail?article=the-impact-of-the-competitive-strategy-on-the-success-of-wine-companies-thecase-of-georgia-

Chokheli E and Narmania D. (2015) Information Tecnnologies In Management And Prospects To Improve Their Use By Georgian Companies. Int J Recent Sci Res, 6(9), 6515-6518.

Dadiani L. (2015) Building Farmer Cooperatives in Georgia: Supporting smallholder farming in the postsocialist context.

Facilitate Sustainable Linkages of Agricultural Cooperatives with Market Players and Extension, Evoluxer S.L International Consulting, 2017.

Keshelashvili G., (2016). General Strategies of Georgian Winemaking Companies' Management in the Conditions of Integrated Development, 23rd International Academic Conference, 27-30 April, Venice, Italy.

http://www.iises.net/proceedings/23rd-international-academic-conference-venice/table-of-content

Keshelashvili G. Jibuti M. (2015). The Commercialization of Ideas and Customer's Needs in the Georgian Market, $15^{\text {th }}$ International Academic Conference, 14-17 April, Rome, Italy.

http://www.iises.net/proceedings/international-academic-conference-rome/front-page

Kharaishvili, E. (2016). 'Small Farm Diversification Opportunities in Viticulture-Winemaking Sector of Georgia '. World Academy of Science, Engineering and Technology, International Science Index 113, International Journal of Social, Behavioral, Educational, Economic, Business and Industrial Engineering, 10(5), 1376 - 1379

Looking Ahead in World Food and Agriculture Perspectives to 2050, Food and Agriculture Organization of the United Nations, 2011.

Mghebrishvili B. (2014). The Ethics and Retail Management Collection of Materials of II International Scientific-Practical Conference. Kiev.

Mikiashvili, N., Lobzhanidze, N.(2016). Important Aspects of the Macroeconomic Stability and Competitiveness of a Small Open Economy. CASE-Center of Social and Economic Research . 25th Anniversary conference. 17-18 November, Warsaw, Poland

Seturidze, R. (2016). Role of the ERP systems in the successful management of Georgian companies. Book of Abstracts Business Systems Laboratory Review. ISBN 9788890824234. Vilnius, Lithuania.

The Role of Family Farming in the Sustainable Development of Agriculture Sector and Poverty Reduction, ISET, Tbilisi, December, 2014.

Toloraia I., Angelovski D., Assessment of the constraints faced by selected farmer organizations and legal entities owned by small scale farmers in Georgia to achieve their potential, 2011. 
Tvalchrelidze A. Silagadze, A. Keshelashvili, G. Gegia D. (2011). Georgia's Social Economic Development Program. "Nekeri", Tbilisi.

www.ifsdeurope.com/getdoc/34/Georgia\%20social\%20economic\%20development\%20program.pdf

Official web-page of Ministry of Agriculture of Georgia, http://moa.gov.ge

Official web-page of National Statistics Office of Georgia, http://geostat.ge/

Official web-page of Agricultural Cooperatives Development Agency, http://www.acda.gov.ge

Official web-page of International Co-operative Alliance, https://ica.coop/ 